Wojciech Kordyzon (ㄱ) http://orcid.org/0000-0002-4291-886X

Uniwersytet Warszawski, Warszawa

wojciech.kordyzon@uw.edu.pl

\title{
Msza przed trybunałem. Personifikacja Mszy w spolszczonym dialogu Bernardina Ochina na tle europejskiej literatury reformacyjnej pierwszej połowy XVI wieku*
}

\begin{abstract}
Mass before the Tribunal. The Personification of the Mass in the Polish Translation of Bernardino Ochino's Dialogue in the Context of the European Reformation Literature of the First Half of the $16^{\text {th }}$ Century

The first part of the paper is to introduce the main motif of Bernardino Ochino's Trajedyja o Mszej (Tragedy on Mass) published in Polish translation in 1560. The work tells the story of a trial of the personified Mass indicted by figures that can be identified with the Reformation and the individuals engaged in it. The Author discusses the structure of this literary dialogue and describes briefly the characters involved in the plot with their polemical background (these include in particular personifications of the Mass, the Lord's Supper, and the Roman Church, as well as figures of the Pope, Satan, Holy Spirit, and a metonymic protagonist named the Lover of God's Glory). The second part presents the context of literary tradition, where Mass was personified for controversial purposes, mainly by authors connected with
\end{abstract}

Praca naukowa finansowana ze środków budżetowych na naukę $\mathrm{w}$ latach 2017-2021 jako projekt badawczy w ramach programu „Diamentowy Grant”. 
the Reformation. The motif of a personified Mass was probably introduced in Swiss pamphlets of the 1520s (Krankheit und Testament der Messe by Niklaus Manuel, Querela Missae by Johannes Atrocianus).

The concept of accusing Mass of dishonesty and performing her trial was recognised as an innovation of English Protestant writings of the late 1540s (esp. William Punt's and William Turner's dialogues). The aforementioned texts are juxtaposed with Ochino's dialogue to show the probable origins of the concept used in his text, as well as to specify additional motifs combined by him (and consequently the Polish translator). The similarities between Ochino's work and the texts chosen, as well as Ochino's connections with the places of publication of these texts, allow us to see them as part of a small yet consistent subtype of Protestant polemical writings, which Ochino chose to use and modify for controversial purposes.

Keywords: Bernardino Ochino, Mass, Lord's Supper, personification, Reformation, trial of Mass, dialogue

W XVI wieku wydano w języku polskim dwa przekłady dialogów Bernardina Ochina (1487-1564), włoskiego teologa i działacza reformacyjnego. Pierwszy, niezachowany, został wydrukowany w 1558 roku w oficynie na zamku Andrzeja Górki w Szamotułach jako O zwierzchności papieskiej ${ }^{1}$ w przekładzie Eustachego Trepki, królewieckiego aktywisty luterańskiego. Drugi dialog ukazał się jako Trajedyja o Mszej w 1560 roku w pińczowskiej drukarni Daniela z Łęczycy z przedmową pióra Franciszka Lismanina, jednego z ówczesnych przywódców obozu ewangelicko-reformowanego w Małopolsce. Tłumacz nie jest znany, choć w dotychczasowej literaturze wskazuje się zarówno na

${ }^{1}$ B. Ochino, O zwierzchności papieskiej nad wszystkim światem krześcijańskim tragedyja krotochwilna, nauki krześcijańskiej barzo potrzebnej, papieskie fałsze okazujacej i burzacej petna, przeł. E. Trepka, Szamotuły: Aleksander Augezdecki, 1558. Unikat Biblioteki Ordynacji Krasińskich w Warszawie nie zachował się, a fragmenty tekstu znane są z artykułu Juliusza Kleinera, „Tragedye” Ochina, „Pamiętnik Literacki” 9 (1910), z. 4, s. 397-418.

${ }^{2}$ B. Ochino, Trajedyja o Mszej, z której każdy snadnie wyrozumieć może początek $i$ wszelaka jej sprawę, i do prawdziwej Wieczerzej Pańskiej właśnie każdy wiedzieć ma, Pińczów: Daniel z Łęczycy, 1560. Autor artykułu pracuje nad edycją krytyczną utworu. 
nakładcę druku, Pawła Lismanina, jego stryja Franciszka, jak i autora poprzedniego przekładu, czyli Trepkę. Okoliczności zainicjowania obu przekładów nie są do końca jasne, choć czasem przypuszcza się, że Franciszek Lismanin spotkał Ochina podczas swojej podróży do Szwajcarii w latach 1553-1555 i przywiózł do Polski rękopisy, które stały się podstawą tłumaczeń ${ }^{3}$.

Celem artykułu jest prześledzenie pokrewieństwa w zakresie topiki pomiędzy Trajedyją o Mszej a pochodzącymi z pierwszej połowy XVI wieku utworami wybranych autorów europejskich, zwłaszcza szwajcarskich i angielskich (Niklaus Manuel, Johannes Atrocianus, Jerome Barlowe, William Roy, William Turner, William Punt). Miejsca wydania omawianych utworów pokrywają się w pewnej mierze $\mathrm{z}$ itinerariuszem Bernardina Ochina, a ich zestawienie $\mathrm{z}$ utworem Włocha pozwoli na przybliżenie funkcji spersonifikowanej Mszy w reformacyjnej literaturze polemicznej. Dyskusje teologiczne nad rolą mszy miały kluczowe znaczenie w ruchu reformacyjnym, ponieważ prowadziły do stawiania pytań zarówno o zasadność i sposób jej

${ }^{3}$ Zagadnienie omawiają szerzej: A. Brückner, O różnowierstwie polskiem słów kilka, „Reformacja w Polsce” 1 (1921), s. 9-11; H. Barycz, Lismanin Franciszek, w: Polski słownik biograficzny, t. 17, Kraków 1972, s. 468; J. Ślaski, Le "Tragedie" di Bernardino Ochino in polacco, w: Movimenti ereticali in Italia e in Polonia nei secoli XVI-XVII. Atti del convegno italo-polacco, Firenza, 22-24 settembre 1971, Firenze 1974, s. 115-116. Dialog O zwierzchności papieskiej na polski przełożono najpewniej z niezachowanego tłumaczenia łacińskiego, a Trajedyje o Mszej - jak zasugerował Barycz - na podstawie nieznanych rękopisów, jedyne bowiem drukowane utwory bliskie wydaniu polskiemu ukazały się w rok po edycji pińczowskiej w Bazylei w języku włoskim (B. Ochino, Disputa intorno alla presenza del corpo di Giesu Christo nel sacramento della cena, Basel: [Peter Perna?], 1561) i łacińskim (idem, Liber de corporis Christi praesentia in coenae sacramento, Basel: Peter Perna, 1561). Różnice pomiędzy tekstami polskim i włoskim omawia Juliusz Kleiner (zob. J. Kleiner, „Tragedye”..., s. 409-417). Ilościowo w stosunku do tekstu włoskiego są one w polskim wydaniu Trajedyi o Mszej duże: za ingerencje (czyli wybór i przełożenie tylko niektórych części potencjalnego pierwowzoru) musiał odpowiadać więc tłumacz lub też przełożono utwór z hipotetycznej, nieznanej krótszej redakcji włoskiej lub łacińskiej (być może owej rękopiśmiennej); te jednak partie, które odpowiadają tekstowi włoskiemu, przełożone zostały bez większych modyfikacji. 
celebracji jako rytuału, który reformatorzy decydowali się najczęściej oczyścić ze wszystkich elementów uznanych za dodatki późniejsze niż czasy apostolskie, jak i o naturę oraz rolę Eucharystii, zwłaszcza jeśli idzie o podważanie doktryny o transsubstancjacji ${ }^{4}$.

Trajedyja o Mszej w polskim wydaniu dzieli się na dwa akty, a jej bohaterowie to w dużej mierze postaci alegoryczne. Pierwsza część dialogu przedstawia historię Mszy: jej nieprawych narodzin i zdobycia dominującej pozycji w świecie chrześcijańskim, druga - proces Mszy przed trybunałem, w którym na wniosek Miłośnika Chwały Bożej sądzi ją sam Duch Święty. W pierwszej scenie pierwszego aktu Szatan zastanawia się, w jaki sposób może najbardziej zaszkodzić ludziom. Decyduje się wykorzystać do tego Papieża i namawia go, by został kochankiem Eklezji, żeńskiej personifikacji w tekście występującej jako Kościół Rzymski ${ }^{5}$ Ta staje się brzemienna. Gdy Papież dowiaduje się o ciąży, natychmiast udaje się do Praktykarza (tj. astrologa), który stawia mającemu się narodzić dziecku horoskop. Wówczas zostaje podjęta decyzja o nadaniu córce imienia Msza, czyli Missa ('zesłana'). Młoda Msza zostaje oddana na wychowanie Mądrości Ludzkiej. W tym czasie poznajemy także Wieczerzę Pańską, która wchodzi w spór z Mszą. Córka papieska pozbywa się rywalki, namawiając swojego ojca, by wtrącił Wieczerzę Pańską do lochu. Drugi akt - rozgrywający się w nieokreślonym odstępie czasu od

${ }^{4} \mathrm{O}$ pierwszych dyskusjach eucharystycznych, zwłaszcza w kontekście Lutra, zob. A.N. Burnett, Karlstadt and the Origins of the Eucharistic Controversy. A Study in the Circulation of Ideas, Oxford 2011, s. 36-76. Podsumowania najważniejszych stanowisk dają: M.L. Mattox, Sacraments in the Lutheran Reformation, w: The Oxford Handbook of Sacramental Theology, ed. by H. Boersma, M. Levering, Oxford 2018, s. 276-281; M. Allen, Sacraments in the Reformed and Anglican Reformation, w: The Oxford Handbook..., s. 290-293; N. Thompson, Eucharistic Sacrifice and Patristic Tradition in the Theology of Martin Bucer, 1534-1546, Leiden 2005, s. 33-71.

${ }^{5}$ Niezgodność rodzajowa jest pochodną łaciny i włoszczyzny, w których pisał Ochino. Decyzja tłumacza o użyciu rzeczownika męskiego mogła być podyktowana przekonaniem, że personifikacje Kościoła (Eklezji) w sztukach wizualnych są najczęściej personifikacjami kobiecymi. Zob. W. Greisenegger, Ecclesia, w: Lexikon der christliche Ikonographie, hrsg. von E. Kirschbaum, Bd. 1, Rom 1968, szp. 562-569. 
wydarzeń z poprzedniej części - rozpoczyna wystąpienie Miłośnika Chwały Bożej, który rozpoznaje w Mszy postać fałszywie podającą się za córkę Chrystusa i zastanawia się, jaki los spotkał Wieczerzę Pańską znaną z Pisma. Udaje się więc do Ducha Świętego i przed jego Boski trybunał wnosi sprawę przeciw Mszy. Ponad dwukrotnie obszerniejszy akt drugi przedstawia przebieg sporu między Miłośnikiem Chwały Bożej a Mszą i Zabobonem (jej „prokuratorem”, czyli obrońcą). Ostateczny werdykt sędziego jest dla Mszy niekorzystny, a wdzięczna Wieczerza Pańska wygłasza końcową przemowę skierowaną do wiernych.

Oś fabularna utworu staje się pretekstem do formułowania wypowiedzi o charakterze teologicznym, a perswazyjny aspekt tekstu leży nie tyle w dyskusjach postaci poświęconych roli katolickiego obrzędu, ile skupia się w samej spersonifikowanej Mszy, której przydany został konkretny sposób mówienia i charakter, a całą „tragedię” odgrywa ona jako pełnoprawna bohaterka oraz uczestniczka przedstawianych wydarzeń. Wykorzystana w utworze formuła dialogu, gatunku szczególnie często stosowanego w rozmaitych polemikach o charakterze naukowym i filozoficznym, stała się ważnym sposobem wypowiedzi dla pisarzy okresu reformacji ${ }^{6}$. Polemika w dialogu Ochina nie została wyrażona w wywodzie o charakterze historiograficznym, które

${ }^{6} \mathrm{O}$ genologii i tematyce dialogu niemieckiego w kontekście reformacyjnych dyskusji religijnych zob. na przykład: J. Kampe, Problem „Reformationsdialog“. Untersuchungen zur einer Gattung im reformatorischen Medienwettstreit, Tübingen 1997, s. 80-116. Na gruncie polskim problemem dialogu w perspektywie dawnej kultury dysputacyjnej zajmowała się (dotykając także zagadnienia dialogów religijnych) Magdalena Ryszka-Kurczab (Mimetyczny charakter szesnastowiecznych dialogów. Preliminaria, w: „Wszystko tu najdzie, co wy macie w głowie”. Świat prozy staropolskiej, red. E. Lasocińska, A. Czechowicz, Warszawa 2008, s. 63-73), a w odniesieniu do pisarstwa Reja Jerzy Ziomek (Mikołaja Reja „Krótka rozprawa” $i$ „Kupiec”. Problemy dialogu i dramatu, w: Mikołaj Rej w czterechsetlecie śmierci, red. T. Bieńkowski, J. Pelc, K. Pisarkowa, Wrocław 1971). Zob. także funkcjonalny podział podgatunków dialogu opracowany w badaniach nad łacińskimi dialogami średniowiecznymi: C. Cardelle de Hartmann, Lateinische Dialoge 1200-1400. Literaturhistorische Studie und Repertorium, Leiden 2007, s. 29-57. 
występowały również w polskojęzycznych dyskusjach reformacyjnych ${ }^{7}$, ale za pomocą poglądowej literackiej fabuły tylko metaforycznie odnoszącej się do materii historycznej, za jaką uznawano działalność wczesnego Kościoła rzymskiego emancypującego się do osobnej siły politycznej (co widoczne było zwłaszcza w dyskusjach o tzw. supremacji papieskiej). Mszę poznaje czytelnik jako integralną postać, która ma zarówno swoją historię rozwijaną w ciągu fabularnym, jak i swoje przekonania, które przedstawia, gdy zabiera głos. Trajedyja w syntetyczny sposób łączy więc poszczególne „błędy doktrynalne” w polemikach przypisywane obozowi rzymskiemu $\mathrm{z}$ antypatyczną postacią zaprezentowaną w utworze, a mającą obrazować samą naturę skażonego Kościoła. „Ludzki” rodowód Mszy, czyli uznanie, że nie pochodzi ona bezpośrednio od Chrystusa i nie została przez Niego ustanowiona, stanowił jeden z głównych argumentów ewangelickich, zobrazowanych w utworze włoskiego teologa.

\section{Proces Mszy w Trajedyi Ochina}

Formuła procesowa jako oś konstrukcyjna utworu znajduje odzwierciedlenie w tradycji średniowiecznej. Najbardziej znanym przykładem jest wielokrotnie naśladowany Proces Szatana (Processus Sathanae) Bartola z Sassoferato (1313-1357), włoskiego jurysty wykładającego w Perugii. Choć istnieją różne warianty tego dydaktycznego utworu służącego wykładowi prawa kanonicznego, to rama fabularna wariantów pozostaje zbliżona: Szatan wnosi przed sąd Chrystusa pozew przeciwko grzesznej ludzkości, a jej obrończynią zostaje Maria, która okazuje się biegłą prawniczką i biblistką ${ }^{8}$. Dialog powraca

7 Zob. na przykład: [E. Trepka?], Książki o tym, skąd wzięło początek słowo Boże, Królewiec: Hans Daubmann, 1557; V. Wanner, Praktyka o mszy, co o niej a jako rozumieć mamy, [przeł. W. Nowomiejski], Królewiec: Hans Daubmann, 1559.

8 Zob. C. Cardelle de Hartmann, Lateinische Dialoge..., s. 233-241. Zob. także: J. Wojtkowski, Kanoniczne podstawy dialogu Maryi z szatanem w procesie szatana 
także w nowożytnych redakcjach, na przykład u Ulricha Tenglera w zwodzie prawnym dla laików zatytułowanym Laienspiegel (1509)9 w którym sąd odprawia jednak cała Trójca Święta. Pogłosem tej tradycji jest też polski Postępek prawa czartowskiego (1570), wydany zresztą przez Cypriana Bazylika, czyli w kręgu ewangelickim (brak tu więc postaci Marii czy świętych, choć w samym utworze nie występują inne jednoznaczne stwierdzenia pozwalające na konfesyjne zaklasyfikowanie polskiego przekładu) ${ }^{10}$.

Kluczowy dla niniejszych rozważań będzie sposób konstruowania protagonistów w Trajedyi, której głównymi bohaterami są postaci funkcjonujące w tradycji religijno-literackiej (Szatan, Duch Święty) oraz liczne personifikacje zaludniające utwór a sprawcze dla rozwoju akcji oraz przebiegu dyskusji. Te drugie można podzielić na dwa typy: metonimicznych figur reprezentujących większe grupy lub instytucje oraz prozopopeicznych uosobień abstrakcyjnych zjawisk. Do pierwszego typu należy zaliczyć postaci Papieża jako figurę służącą do formułowania wypowiedzi obnażających fałsz całej instytucji papiestwa, Kościół Rzymski - w podobny sposób postać będącą reprezentacją organu chrześcijaństwa poddawanego krytyce, oraz Miłośnika Chwały Bożej jako swoistą realizację moralitetowego everymana, którego słowa i czyny mają stanowić zachętę do podjęcia pilnych działań przez całą rzeszę chrześcijan - czytelników Trajedyi. Zjawiska abstrakcyjne są zaś reprezentowane przez tytułową Mszę wraz z jej obrońcą Zabobonem oraz Wieczerzę Pańską, personifikację sakramentu ewangelickiego, przeciwstawioną „,zabobonnemu” rytuałowi katolickiemu.

przeciwko rodzajowi ludzkiemu Bartola z Sassoferrato, „Studia Warmińskie” 41/42 (2004/2005), s. 181-189.

9 U. Tengler, Layenspiegel von rechtmässigen Ordnungen in burgerlichen und peinlichen Regimenten, Augsburg: Johann Otmar, 1509, k. P 3 v.-R 5 r. Zob. także: P.A. Russell, Lay Theology in the Reformation. Popular Pamphleteers in Southwest Germany 1521-1525, Cambridge 2002, s. 41-42; I.B. Schairer, Das religiöse Volksleben am Ausgang des Mittelalters nach Augsburger Quellen, Leipzig 1914, s. 83.

${ }_{10}$ Postępek prawa czartowskiego przeciw narodowi ludzkiemu, [Brześć Litewski: Cyprian Bazylik, 1570]. Ostatnia edycja: Postępek prawa czartowskiego przeciw narodowi ludzkiemu, oprac. A. Kochan, Wrocław 2015. 
Batalia sądowa w Trajedyi jest nierówna, a kolejne sesje trybunału przedstawiane w utworze zmierzają do ujawnienia głupoty Mszy, jej fałszu i kłamliwości. Jednak to same wypowiedzi postaci implikują ich ocenę, dialog bowiem pozbawiony jest ramy narracyjnej, która mogłaby modulować odbiór poszczególnych kwestii. Funkcję taką pełniły poprzedzające utwór parateksty, także perswazyjnie nastrajające lekturę, czy autorska decyzja dotycząca sposobu konstruowania przedstawianego świata, jak choćby nadawa nie postaciom znaczących imion. Na przykład wypowiedzi sędziego w większości mają zachować pozór bezstronności i obiektywności przeprowadzanego sądu, Duch Święty zapewniał bowiem:

Wszak jeśli się tu twoja niewinność okaże, tedy my będziemy wiedzieć, jako w tym postąpić, a co z tym będziemy uczynić mieli. Okażeli się też to, iż tu winni będziecie, wszak się słuszne a przystojne i temu karanie znajdzie ${ }^{11}$.

Wbrew temu założeniu Msza jednak jeszcze w pierwszej scenie drugiego aktu, wezwana przed rozpoczęciem procesu na wstępne przesłuchanie przez sędziego, zaprezentowała się jako pyszna i nierozważna, z góry przekonana o swojej racji i jawnie wyśmiewająca oskarżenia:

Pewnie, iż się temu śmiać muszę, gdyż to czując do siebie, żem jest na świecie naświętszą i nachwalebniejszą i mam tu być obwinioną a oskarżoną, by więc jaka łotrzyni. [...] Nietajne to są rzeczy, że zacność słowa a świątość moja jest dawna, od wiela synodów potwierdzona, dekrety papieskimi uprzywilejowana, od szkolnych teologów a od onych uczonych wykładaczów Pisma w mojej świątości jest zacnie okazana, od kanonistów i od wszystkich krześcijanów wszędym jest wdzięcznie przyjęta, a słowem Bożym na wszystek świat jestem sławnie zalecona. K temu wielkiemi cudy a niesłychanymi dziwy jestem umocniona, a k temu, iż wszem $<\mathrm{w}>$ onym długiem a starym zwyczaju przez niemały czas trwam i trwać będę ${ }^{12}$.

\footnotetext{
11 B. Ochino, Trajedyja..., k. $\mathrm{P}_{3}$ r.

12 Ibidem, k. $\mathrm{P}_{3}$ r. $-\mathrm{P}_{4} \mathrm{v}$.
} 
Jej niewiarygodność przejawia się wielokrotnie. Msza z początku sama podjęła się swojej obrony, jednak nie będąc w stanie podołać argumentom przeciwnika, zmuszona została do znalezienia reprezentanta. Wybór padł na figurę o imieniu znaczącym: jej obrońcą został wspomniany Zabobon, sprawny retorycznie, ale w kolejnych sesjach tracący impet i płynność argumentacji wobec „niezbitych” dowodów Miłośnika Chwały Bożej. Pobożny „instygator” (czyli powód) był dla Zabobonu przeciwnikiem niełatwym, wytaczał bowiem nie tylko argumenty teologiczne (dokonując interpretacji fragmentów biblijnych), lecz posługiwał się także określeniami osadzonymi w ówczesnym repertuarze polemicznych epitetów na określenie Rzymu i katolickich ceremonii, mającymi zbić przeciwników z tropu, obrazić ich, na przykład:

Nad inne wszystki błędy, niezbożności, bluźnierstwa a sprośności, które u tej nieszczęsnej merchy [= nierządnicy - W.K.] paniej Mszej najdujemy, jest jedna rzecz przed wszystkim nasprośniejsza, nagorsza, naprzeklętsza i nanieznośniejsza, a to tak, iż ta marna zdradnica ustawicznie znowu krzyżuje Krystusa Pana ${ }^{13}$.

Msza nazywana jest więc przez swojego oskarżyciela bezustannie „merchą”, „zdradnicą”, „fałszerką”, „złośnicą” czy „wszetecznicą”. W nieco późniejszym Apocalypsis (1565) Mikołaja Reja podobne określenia padają w odniesieniu do Nierządnicy Babilońskiej, przez ewangelików interpretowanej jako personifikacja Kościoła katolickiego: „ukazał mu tę złośnicę a tę cudzołożnicę na bestyjej żółtej o siedmi głowach”, „komu więcej wierzyć mamy, jeśliże [...] kochankom tej małpy wszetecznej, jeśliże [...] Duchowi świętemu”, „ta

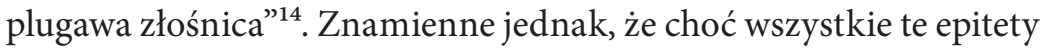
$\mathrm{w}$ obu tekstach są semantycznie powiązane $\mathrm{z}$ niewiernością i zdradą, to w Trajedyi precyzyjne określenie „cudzołożnica” zostało

${ }^{13}$ Ibidem, k. Y ${ }_{7}$ r. $-\mathrm{Y}_{7} \mathrm{v}$.

${ }^{14}$ M. Rej, Apocalypsis, red. W. Kriegseisen, oprac. M.M. Kacprzak, S. Kawczyński, J.T. Maciuszko, I. Winiarska, Warszawa 2005, s. 324, 329, 334. 
zarezerwowane wyłącznie dla postaci Kościoła Rzymskiego, nie protagonistki. Zapewne wiąże się to $\mathrm{z}$ chęcią podkreślenia, że to matka Mszy dopuściła się z Papieżem aktu cudzołóstwa, zdradzając tym samym jedynego oblubieńca - Chrystusa.

Juliusz Kleiner, raczej negatywnie nastawiony do przekładów utworów Ochina ze względu na dużą liczbę antykatolickich inwektyw, doceniał jednak w Trajedyi to, co nazwał „rysem psychologicznym” postaci, przekonując, że dyskusje bohaterów przepełnione emocjami i dużą liczbą prawdopodobnie kolokwialnych zwrotów zyskiwały na wiarygodności, a spór - ludzki wymiar (choć był toczony przez personifikacje pojęć abstrakcyjnych) ${ }^{15}$. Zgodność świata przedstawionego utworu z realiami procesowymi dawnej Polski mogłaby to wrażenie pogłębić - tak jak w innych utworach proreformacyjnych, na przykład w Rejowym Kupcu (1549) ${ }^{16}$ - jednak zagadnienie to wymaga z pewnością osobnych rozważań.

Nie rozstrzygając w tym miejscu o relacjach między historycznymi zwyczajami procesowymi a sądem przedstawionym w Trajedyi, wypada zwrócić uwagę, że oskarżona jest personifikacją żeńską, co samo w sobie ustawia ją w konkretnej pozycji w oczach czytelnika. Należy przypomnieć, że w XVI wieku kobiety nie mogły z reguły występować w sądzie w swoim imieniu ${ }^{17}$. Inaczej niż w różnych redakcjach Processus Sathanae, w których Maria jako obrończyni ludzkości erudycyjnie dowodzi, że ma prawo wystąpić w obranej roli przed trybunałem ${ }^{18}$, z początku butna Msza musi przyznać Miłośnikowi Chwały Bożej: „radeś, iżeś na mię, na prostaczkę trafił, więc

15 Zob. J. Kleiner, „Tragedye”..., s. 409.

16 Zob. A. Kochan, Kupiec przed polskim sadem. Uwagi i komentarze do „Kupca” Mikołaja Reja, „Pamiętnik Literacki” 94 (2003), z. 4. Notabene Janusz T. Maciuszko zwraca uwagę, że Rej w Kupcu jest raczej „propagatorem jądra reformacyjnych tez” (J.T. Maciuszko, Mikołaj Rej. Zapomniany teolog ewangelicki z XVI w., Warszawa 2002, s. 265) niż autorem wyczerpująco przedstawiającym konkretne protestanckie stanowisko teologiczne.

17 S. Płaza, Historia prawa w Polsce na tle porównawczym, cz. 1, Kraków 2003, s. 439. Samodzielnie występować mogły jedynie wdowy.

18 Zob. J. Wojtkowski, Kanoniczne podstawy..., s. 183. 
tu chcesz nade mną rozumem swym przewodzić”" ${ }^{19}$. Sądzący Duch Święty przed pierwszą sesją trybunału tymi słowami nakazuje Mszy znaleźć obrońcę: „a ty, pani, nie wiem, jeśli dobra, gdyż sama w swych rzeczach słusznie postępować nie umiesz" ${ }^{20}$. Mimo to Msza w trakcie procesu ujawnia swoją impulsywność i kilkukrotnie wyrywa się do odpowiedzi, na przykład:

Jużci i sama nie mogę zamilczeć, a muszęć na to odpowiedzieć. Widzę, że nic w sobie nie chcesz zataić, a rad by wszystko, co snadź i nagorszego na mię wywarł. Ale barzo się na tym mylisz ${ }^{21}$.

Postawa Mszy kontrastuje z postępowaniem Wieczerzy Pańskiej, realizującej dawny ideał kobiety cichej, pokornej i znającej swoje miejsce w ówczesnym porządku, czym miała przypuszczalnie zaskarbić przychylność czytelnika. Do jedynej bezpośredniej konfrontacji bohaterek dochodzi jeszcze w pierwszym akcie, traktującym o genezie Mszy i przed uwięzieniem Wieczerzy Pańskiej. Personifikacja ewangelickiego sakramentu udała się do swojej rywalki, by napomnieć ją w chrześcijańskim duchu i pokornie prosić o zachowanie skromności:

Wieczerza Pańska: W zwierzchownej postawie a w zwierzchownym okazaniu możesz się zdać niejako świętą, ale iżby to w rzeczy było pewnie o sobie tego nie rozumiej, a nic tak jest, bo i Krystus Pan tak powiedział, iż to, co tu ludziom wedle świata miło, tym się Pan Bóg brzydzi.

Msza: Idź oto a wędruj precz, głupia prostaczko, a daj mi pokój.

Wieczerza Pańska: Prostotą gołębiczki iście się Pan Bóg nigdy nie brzydzi ${ }^{22}$.

${ }_{19}$ B. Ochino, Trajedyja..., k. Q $\mathrm{Q}_{6}$.

${ }^{20}$ Ibidem, k. Q $\mathrm{v}$.

${ }^{21}$ Ibidem, k. Ss ${ }_{5}$ v. Także wcześniej atakuje Miłośnika: „Docirajże, bo masz czas. Widzę, żeć barzo wszystki moje postępki nie w smak. [...] Nie ciesz się tym, iż ci tu wolno, co chcesz, mówić o mnie" (ibidem, k. Bb ${ }_{6} \mathrm{v} .-\mathrm{Bb}_{7} \mathrm{r}$.).

${ }^{22}$ Ibidem, k. $\mathrm{M}_{7} \mathrm{v} .-\mathrm{M}_{8} \mathrm{r}$. 
Scena była sposobnością, by przedstawić czytelnikowi w pełnej krasie pierwszy popis pychy Mszy, odchowanej przez piastunkę o znaczącym imieniu - Mądrość Ludzka (którą łatwo przeciwstawić funkcjonującej w tradycji Mądrości Bożej, niewystępującej jednak jako postać w utworze).

Podczas procesu Wieczerza Pańska pozostaje właściwie nieobecna. Przez cały ten czas w jej imieniu występuje Miłośnik Chwały Bożej, od niego także wyszła inicjatywa osądzenia Mszy. Wieczerza Pańska zabiera głos dopiero w ostatniej scenie, już po korzystnym dla niej wyroku Ducha Świętego. W swojej finalnej przemowie reasumuje wszystkie teologiczne argumenty pojawiające się w trakcie sądowej dysputy, podkreślając przy tym swoje bezpośrednie pochodzenie od Chrystusa: jest Jego córką - inaczej niż Msza, która jest „córką" Szatana, owocem grzechu Papieża i Kościoła Rzymskiego ${ }^{23}$.

Takie zastosowanie schematu procesowego w polemicznym dialogu religijnym ma swoje znamienne konsekwencje. Na przykład w Rejowym Kuрсu krytyka spada przede wszystkim na postaci o charakterze metonimicznym. Bohaterowie - Książę, Biskup, Gardyjan i tytułowy Kupiec - reprezentować mogą najwyżej określone społeczne grupy, a największą pobożność wykazuje ten, którego stereotyp na to nie wskazuje. Umoralniająca fabuła stała się dla Nagłowiczanina pretekstem do wyrażania stanowisk o charakterze polemicznym. Inaczej jest w wypadku Trajedyi, w której polemika o charakterze doktrynalnym ma zasadnicze znaczenie dla konstrukcji całego utworu. Postaci wyobrażające szersze grupy: Papież, Kościół Rzymski czy wreszcie w zamyśle wzorcotwórczy Miłośnik Chwały Bożej, są tylko narzędziami sporu, ale właściwy konflikt rozgrywa się na poziomie twierdzeń teologicznych: wszystko to, co uosobione w postaci Mszy (czyli konkretna ceremonia kościelna i stojące za nią dogmaty czy rozstrzygnięcia egzegetyczne), zostaje napiętnowane, zwycięska zaś strona zyskuje okazję, by zwrócić się do wiernych i napomnieć o kształcie docelowego porządku, do którego mają zmierzać.

${ }^{23}$ Zob. ibidem., k. Ww $\mathrm{Ww}_{3}$ r. $-\mathrm{Yy}_{4} \mathrm{r}$. 


\section{Personifikacje Mszy w literaturze reformacyjnej pierwszej połowy XVI wieku}

Nie tylko formuła procesowa, ale i personifikacja Mszy w dawnym piśmiennictwie ma swoją tradycję. Jej przybliżenie pozwoli lepiej zrozumieć zarówno konwencję, do jakiej mógł odnosić się Ochino oraz pośrednio polski tłumacz, jak i pewne innowacje wprowadzone do omawianego utworu. W reformacyjnych utworach polemicznych najprawdopodobniej pierwsze wystąpienie Mszy jako uosobionej bohaterki literackiej zaobserwować można w utworach szwajcarskiego pisarza i artysty, Niklausa Manuela (1484-1530). Niemieckie dialogowane pamflety, posiadające liczne wydania od 1528 roku, znane pod tytułami Der Krankheit der Messe i Der Testament der Messe ${ }^{24}$, zawierają satyryczny wizerunek chorującej i umierającej Mszy.

$\mathrm{W}$ pierwszym $\mathrm{z}$ nich, niedługim prozatorskim dialogu, rozmawia kilka postaci, między innymi Papież, Kardynał i lekarze: doktor Rundeck (w którym rozpoznaje się postać katolickiego polemisty Lutra, Johanna Ecka), aptekarz Hoioho (identyfikowany jako Johann Faber, katolicki teolog, uczestnik pierwszej dysputy w Zurychu w 1523 roku jako przeciwnik Huldrycha Zwinglego) i inni. Msza nie pojawia się jako ich rozmówczyni, ale jest przedmiotem dyskusji. Kardynał donosi Papieżowi, że w Niemczach Msza popadła w okropną biedę. Jest tam oskarżana i prześladowana, a z żałości zapadła na ciężką chorobę. Jej przeciwnicy mieli zrzeszać się pod imieniem Wieczerzy Pańskiej. Opisy dolegliwości cierpiącej i próby zastosowania

${ }^{24}$ Edycja krytyczna: N. Manuel, Krankheit und Testament der Messe, w: idem, Werke und Briefe. Vollständige Neuedition, hrsg. von T. Hengartner, P. Zinsli, Bern 1999, s. 449-471 (edycja Kranheit der Messe na podstawie rkpsu Zentralbibliothek Zürich, sygn. Res. 898, a Testament der Messe na podstawie drukowanego wydania „a”: [N. Manuel], Ein kleglich bott / schafft dem Bapst zuokom= / me, antreffend des gantzen Bapstumbs [...], [b.m.] 1528 [1540?], nr M 748 w bibliografii Verzeichnis der im deutschen Sprachbereich erschienenen Drucke des 16. Jahrhunderts, http://www.vd16.de/, dostęp: 20.12.2018). Omówienie wydań z lat 1528-1569 zob. N. Manuel, Krankheit und Testament..., s. 440-448. 
rozmaitych kuracji (głównie ośmieszających rzekomo wybitnych lekarzy) kończących się niepowodzeniem przedstawiają Mszę jako milczącą pacjentkę. Śmiertelnej przypadłości uleczyć się jednak nie dało: już na samym początku jeden z przyzwanych lekarzy, doktor Rundeck, zauważył, że Msza urodziła się pod złym znakiem, więc wszelkie starania będą bezowocne ${ }^{25}$. Podobnie więc jak w późniejszej Trajedyi, w której Praktykarz postawił horoskop mającej się narodzić Mszy i przepowiedział Papieżowi, że jego córka osiągnie ogromne zaszczyty, lecz czeka ją też niechybna utrata mocy i wpływów ${ }^{26}$, szwajcarski dialog upewnia czytelnika na samym początku, że upadek Mszy jest nieuchronny, jej los został bowiem zapisany w gwiazdach i nie da się go odmienić ${ }^{27}$. Dlatego pod koniec utworu lekarze nie widzą już sensu, by dalej leczyć swoją pacjentkę, i obłudnie zapewniają, że Msza ma się wyśmienicie.

Swoistym epilogiem do dialogu jest Testament der Messe, który stanowi monolog umierającej bohaterki, opuszczonej już przez zajmujących się nią doktorów. Bezradna Msza spisuje swoją ostatnią wolę. Duszę przekazuje swojemu „bożkowi i stwórcy Papieżowi”28, mając przy tym nadzieję, że łzy całego duchowieństwa będą zraszać ziemię na jej grobie ${ }^{29}$. Dalszym instrukcjom nadano kształt porad informujących, co mają uczynić wierni podążający za zaleceniami reformatorów z pozostałymi niepotrzebnymi katolickimi paramentami.

25 N. Manuel, Krankheit und Testament..., s. 456: „Doctor Rundegk: «So wol her / wir wo wlend von sachen radten / Erstlich wil ich ansehen / die Meß syge in eim

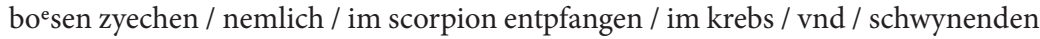
Mon geborn [...]». Doctor Heyoho: «Ja herr Doctor / jr redend recht / un ${ }^{\mathrm{d}}$ von der wurtzel diser sach / es haben vil jr kunst daran vnnützlich verschlissen»”.

${ }^{26}$ B. Ochino, Trajedyja..., k. E $\mathrm{E}_{4} \mathrm{r}-\mathrm{E}_{4} \mathrm{v}$.

27 O wykorzystaniu argumentów astrologicznych w polemikach reformacyjnych zob. R.B. Barnes, Astrology and Reformation, Oxford 2016.

${ }_{28}$ N. Manuel, Krankheit und Testament..., s. 467: „jrem Go ${ }^{e} t z$ vn ${ }^{\mathrm{d}}$ scho ${ }^{\mathrm{e}}$ pffer dem Bapst".

${ }^{29}$ Ibidem: „Min lychnam soll besttatet werden vnder die ougen der gatzen Pfaffheyt / so tropffet mir das wiewasser vff das grab on vnderlaß: dann sy werden mich trülich beweinen". 
Msza prosi, by oddać jej przyjaciołom święte sprzęty na cele świeckie, na przykład kamień ołtarza na kuchenną ladę, oleje z lampy doktorowi Eckowi, by namaścił nimi swoje skore do krzyku gardło, a dwa świeczniki przeciwnikom reformacji, by mieli więcej światła do studiowania Pisma. Te prześmiewcze instrukcje były poręcznym nośnikiem do wyrażenia treści polemicznych, odnoszących się do poszczególnych elementów związanych z tradycyjnymi rytuałami wokół celebracji mszy.

Johannes Atrocianus, bazylejski polemista szwajcarskich reformatorów, zaproponował nieco inną formułę wykorzystania personifikacji Mszy. W niedługim poemacie pisanym dystychem elegijnym zatytułowanym Querela Missae (1529) humanista kazał Mszy wygłosić skargę na swój upadek. Wzorując się na Erazmowej Querela Pacis (1517), Atrocianus oprócz wzoru literackiego przejął od Rotterdamczyka także stanowisko bardziej zniuansowane niż proreformacyjne pamflety. Msza w swoim lamencie widzi siebie jako ofiarę zmanipulowanego tłumu, wśród którego wzbudzono do niej niechęc $c^{30}$. Utwór służy podkreśleniu demagogicznego aspektu agitacji przeciw Mszy, która referuje nie tylko zarzuty swojego głównego przeciwnika o imieniu Crispus, lecz także podburzonych przez niego kobiet rzucających w stronę Mszy różne oskarżenia ${ }^{31}$. Zauważa jednak, że powody niezadowolenia nie są bezpodstawne i wskazuje przede wszystkim na złe prowadzenie się duchowieństwa, panującą w tym stanie rozwiązłość i dążenie do bogactwa ${ }^{32}$. Msza wzywa - poniekąd - do sprawiedliwego jej osądzenia.

30 Zob. C. Guerra, Die Werke im Überblick, w: Johannes Atrocianus. Text, Übersetzung, Kommentar, hrsg. von C. Guerra, H. Harich-Schwarzbauer, J. Hindermann, Hildesheim 2018, s. 21.

${ }^{31}$ I. Atrocianus, Querela Missae [...] opusculum elegans ac recens natum atque excusum, Basel: Johannes Faber aus Emmich, 1529, k. 8r.-8v. (VD16 A 4024).

32 Zob. na przykład ibidem, k. 19r.: „Et dicam, lector candide, Missa tibi: / Sunt mistae turpes vitam qui vivere turpem / Consuerunt, captos quos trahit ipsa Venus / Et qui divitias sub nomine quaerunt, / Et quaerunt omni tempores divitias". 
Temat mszy został podjęty przez pisarzy reformacji angielskiej mniej więcej w tym samym czasie: w 1528 roku, jeszcze przed oficjalnymi aktami prawnymi króla Henryka VIII z lat trzydziestych XVI wieku, ukazał się w Strasburgu obszerny satyryczny dialogowany poemat Jerome’a Barlowe’a i Williama Roye’a znany współcześnie jako Rede me and be nott wrothe (od incipitu motta $\mathrm{z}$ pierwszej karty druku) ${ }^{33}$. Tekst dotyka różnych zagadnień: krytyki mszy katolickiej, zakonników, doktryny o usprawiedliwieniu (prowadzonej z luterańskiej perspektywy) czy wreszcie lokalnie - krytyki działań arcybiskupa Yorku, kardynała Thomasa Wolseya, oskarżanego tu przede wszystkim o próby opóźnienia akcji reformatorskiej. Jednak to pierwszy z tych problemów przyczynił się do nadania utworowi zwyczajowego tytułu: The Burying of the Mass. Choć ostatecznie współcześni wydawcy uznali ten tytuł za zwodniczy, to warto zauważyć, że między innymi John Foxe już w 1530 roku w ten sposób tytułował dzieło ${ }^{34}$. Nawet jeśli ostatecznie doprowadziło to do mylnych przekonań o treści całości, to na pewno pozwala zaobserwować, która część tekstu wydała się angielskiemu pisarzowi istotna. Inaczej niż u Atrocianusa „lamentacja” (Lamentacion, w. 110-349) poprzedzająca właściwy dialog jest ironiczna i wyraziście parodystyczna. To wypowiedź rzymskokatolickiego księdza, który rozpacza nad śmiercią Mszy, powtarzając wpadający w ucho refren: „Seynge that gone is the Masse, / Nowe deceased alas, alas"35. Lamentujący wymienia tych, którzy Mszę będą opłakiwać: biskupów i kardynałów, wspomina o potędze, którą Msza im zapewniała. Zauważa też z żalem, że po jej śmierci trzeba będzie się wyrzec wszystkich związanych z nią kosztowności: złotych krzyży

${ }_{33}$ Edycja krytyczna: J. Barlowe, W. Roy, Rede me and be nott wrothe, ed. by D.H. Parker, Toronto 1992. Pierwodruk: [J. Barlowe, W. Roy], Rede me and be nott wrothe for I saye no thynge but trothe. I will ascende makynge my state so hye, that my pompous honoure shall never dye, [Strasbourg: Johannes Schott, 1528]. Zob. A.W. Pollard, G.R. Redgrave, Short Title Catalogue, $2^{\text {nd }}$ ed., London 1976-1991 (dalej jako: STC), www.estc.bl.uk (dostęp: 20.12.2018): 21427.

34 Zob. D.H. Parker, Prologue, w: J. Barlowe, W. Roy, Rede me..., Toronto 1992, s. 4.

35 J. Barlowe, W. Roy, Rede me..., Toronto 1992, s. 60 i nn. 
i pierścieni, cennych kamieni, ozdobnych stołów, aksamitnych szat. Msza jako postać jest więc w satyrze nieobecna, ale została uosobiona koncepcyjnie, a więc pośrednio, poprzez opłakiwanie jej jako osoby zmarłej. Stało się to pretekstem do wyliczenia wszystkich zarzutów wobec ceremonii wysuwanych przez stronę ewangelicką. Zabieg ten jest podobny do zastosowanego w satyrze Manuela, chociaż całość pozostaje mniej rozbudowana.

Tekst wznowiono jeszcze w 1546 roku (choć również poza Wyspami Brytyjskimi) ${ }^{36}$, a już niedługo potem, od około 1548 roku, można zaobserwować prawdziwy wysyp angielskich utworów, w których występuje spersonifikowana Msza. Spośród wielu satyr przypisywanych Luke'owi Shepherdowi na uwagę zasługują dwie wydane najpewniej $\mathrm{w} 1548$ roku: The Upcheringe of the Messe $e^{37}$ oraz Pathose ${ }^{38}$. Pierwszy $\mathrm{z}$ utworów bliski jest założeniom adoksografii: niedługa poetycka wypowiedź skonstruowana jest jako pochwała Mszy wygłoszona przez katolickiego kapłana, jednak wszystkie wymieniane cechy adresatki laudacji w rzeczywistości stawiają ją w jak najgorszym świetle. Koncepcja utworu pobrzmiewa echem Erazmowej Pochwały głupoty (1509), repertuar zarzutów zaś nie różni się zbytnio od innych wypowiedzi stronnictwa reformacyjnego: istnienie Mszy nie znajduje poparcia w Piśmie i stanowi papieski (a więc ludzki) wymysł, łacińska liturgia jest celebrowana w zbędnym bogactwie i niezrozumiała dla wiernych, a ci ponadto przypisują obrzędowi moce magiczne. Msza nie wypowiada się w utworze, ale także tutaj znajduje zastosowanie zabieg polegający na jej uosobieniu, tyle że poprzez wypowiedzi innych postaci.

${ }^{36}$ Pod tytułem: The boke reade me frynde and be not wrothe, for I saye nothynge but the trothe. The byshoppes speake in the Cardynall. I wyll ascende makynge my state so hye, that my pompouse honoure shall neuer dye, [Antwerpen?] 1546 (zob. STC: 21428).

37 L. Shepherd, Upcheringe of the messe, London: John Day, William Seres, [1548] (zob. STC: 17630). Cytowana edycja w: An Edition of Luke Shepherd's Satires, ed. by J. Devereux, Tempe (Ariz.) 2001, s. 15-25.

38 [L. Shepherd], Pathose or An inward passion of the pope for the losse of hys daughter the masse, [London: John Day, William Seres, 1548] (zob. STC: 19463). Cytowana edycja w: An Edition of Luke Shepherd's Satires, s. 26-48. 
Pocieszający Mszę ksiądz nazywa Mszę „biedną” („pore”, w. 143), wymieniając wszystkie niezasłużone według niego epitety, jakimi się ją określa, jak choćby nazywanie jej „nierządnicą”, „morderczynią’ (Chrystusa - bo składa Go w ofierze) czy w zgodzie ze znaną z innych pamfletów genealogią - „córką papieża”39. Kilkakrotnie ksiądz wypowiada też w jej kierunku słowa pożegnania, podkreślając przy tym, że jej odejście jest już nieuchronne ${ }^{40}$.

Pathose, czyli, jak głosi podtytuł, „wewnętrzne wzburzenie papieża z powodu utraty jego córki Mszy”, również stanowi monolog dotyczący Mszy, tyle że wygłaszany przez samą głowę Kościoła. Koncepcja fabularna utworu zbliżona jest do koncepcji pamfletu Manuela i bliższego językowo wzorca w Rede me: w obliczu wielości ataków ze strony reformatorów (wśród których pojawia się zresztą i „szczekający Bernardinus [Ochino - W.K.]” - „barkinge Bernardinus”, w. 519) papież ubolewa nad cierpieniami swojej córki, obawiając się także, by jej śmierć nie przyniosła kresu jego panowaniu i bogactwu (zob. w. 316350). By uchronić słabnącą Mszę, prosi o wsparcie rozmaite pogańskie bóstwa, zwłaszcza Ceres (jako boginię płodności powiązaną tu z chlebem) i Bachusa (jako bożka wina), wyrażając nadzieję na docenienie przez nich składanej podczas mszy ofiary, na którą Chrystus miał pozostawać obojętny. Papież uzupełnia także genealogię swego „rodu” i mówi o Plutonie (które to imię rzymskiego boga bywało także stosowane na określenie diabła) jako o „dziadku” (w. 726).

Około roku 1548 wydano również dwa dialogi (w ciągu roku oba wznowiono), w których Msza występuje już jako bohaterka rozmowy. Są to: A new dialogue wherein is conteyned the examinatio[n] of

39 L. Shepherd, Upcheringe..., Tempe (Ariz.) 2001, s. 19, w. 144-151: „What did I call hir pore? / Naye some wyl cal hir whore / And stireth a great vprore / Some cal hir popes daughter / Some sayes she mad manslaughter / Some turne hir to a laughter / Some wold they had not sought hir / Som cursseth hym $\mathrm{y}^{\mathrm{t}}$ brought hir / And him that first taught hir".

40 Ibidem, s. 24, w. 347-352: "A good mestres missa / Shal ye go from vs thissa / Wel yet I muste ye kyssa / Alacke for payne I pyssa / To se the mone here Issa / Because ye muste departe". 
the Messe Williama Turnera ${ }^{41}$ oraz Endighment agaynste the Mother Messe Williama Punta ${ }^{42}$. Szczególnie interesująca z perspektywy niniejszego wywodu jest ich fabularna rama, zaskakująco zbieżna $\mathrm{z}$ ramą Trajedyi o Mszej. Bohaterka (czy to jako Mistress Missa, czy też Mother Messe) zostaje w nich postawiona w stan oskarżenia i staje przed sądem.

Wcześniejszy jest prawdopodobnie dialog Turnera i to on zresztą swoją obfitością argumentacji, tokiem akcji spowalnianej przez długie wypowiedzi dyskutujących postaci przypomina utwór Ochina. Dialog Punta Antoinina Bevan Zlatar określa jako bardziej „dramatyczny", ale zwraca też uwagę na jego wtórność wobec utworu Turnera: imiona postaci zostały nieco zmodyfikowane, choć główna fabuła pozostała zasadniczo niezmieniona ${ }^{43}$. Dialog Turnera rozpoczyna się wystąpieniem personifikacji Mszy, która w niedługim monologu wylicza swoje cudowne moce; usłyszana zostaje przez męską personifikację Wiedzy. Uczony i pobożny Knowledge oburza się na słowa Mszy i stawia ją przed sądem. Wytacza przeciwko niej kolejne argumenty, a wreszcie wygrywa sądowe starcie, doprowadzając do wyroku banicji spersonifikowanego katolickiego rytuału.

Nieco inaczej skonstruował swój utwór Punt, gdyż całość otwiera rozmowa personifikacji Prawdy (Verite) i Wiedzy (Knowledge) poświęcona religijnym wieściom „z zagranicy”. Knowledge wylicza

${ }^{41} \mathrm{~W}$. Turner, A new dialogue wherin is conteyned the examinatio $[n]$ of the Messe, and of that kynde of priesthode, whych is ordeined to saye Messe, [London: William Hill, 1548] (zob. STC: 24363). Kolejne wydania: dwa w 1548 (zob. STC: 24361.5, 24362) i jedno w 1549 roku (zob. STC: 24364a). Cytaty ze starodruków angielskich podaję według anglosaskich standardów edytorskich, nie modernizując grafii ani interpunkcji, nie zachowuję jednak długiego $\int$, a abrewiacje, jeśli są jasne, rozwijam bez oznaczania.

${ }^{42}$ W. Punt, Endighment agaynste the Mother Messe, London: William Hill, William Seres, 1548 (zob. STC: 20499). Kolejne wydanie w 1549 roku (zob. STC: 20500.5). Reprint starego druku w: Three Tudor Dialogues, ed. by D. Spurgeon, New York 1978.

${ }^{43}$ Zob. A. Bevan Zlatar, Reformation Fictions. Polemical Protestant Dialogues in Elizabethan England, Oxford 2011, s. 52. 
zasłyszane grzechy Mszy, by uzyskać ich potwierdzenie podczas procesu. Podobnie jednak jak u Turnera Msza zostaje skazana na nieodwołalne wygnanie z królestwa. Warto zauważyć, że spośród omawianych tu utworów angielskich u Punta znajdzie się najwięcej odwołań do lokalnej polityki angielskiej, co jest wyraźnym sygnałem toczącej się wówczas kampanii poprzedzającej debatę dotyczącą Wieczerzy Pańskiej, która miała się odbyć pod koniec 1548 roku w parlamencie w Londynie ${ }^{44}$.

We wszystkich trzech utworach - tak u Ochina, jak i w dialogach angielskich Turnera i Punta - zaobserwować można liczne zbieżności, które przekonują o pokrewnym zamyśle przeprowadzenia krytyki. U Ochina ojcem Mszy jest Papież, matką - Kościół Rzymski. Podobnie u Turnera Mistress Missa przedstawia się jako córka papieża ${ }^{45}$. Brak tej genealogii w dialogu Punta, choć Msza ma braci: Zabobon (Supersticyon) i Idolatrię (Idolatry) ${ }^{46}$.

W dialogu Turnera do procesu Mszy dochodzi, ponieważ pozwał ją naoczny świadek jej przechwałek wygłaszanych w otwierającym tekst monologu, w którym nie tylko odkrywa ona swoje pochodzenie, ale stwierdza też wprost, że łudzi chrześcijan, jakoby miała być ustanowiona przez Chrystusa ${ }^{47}$. Formalnie proces otworzył Master Justice, będący kimś w rodzaju woźnego sądowego, który doprowadził Mszę przed oblicze sędziego Palemona, zapewniającego o obiektywności mającego rozpocząć się sądu ${ }^{48}$.

44 Akcja wydawnicza przeciw mszy związana jest także z działaniami Edwarda VI usiłującego zreformować ceremonie kościelne aktami z grudnia 1547 roku. Zob. D. Spurgeon, Introduction, w: Three Tudor Dialogues, s. vi-ix, xvi-xvii.

${ }^{45} \mathrm{~W}$. Turner, A new dialogue..., k. $\mathrm{A}_{5} \mathrm{r}$.

46 W. Punt, Endighment..., k. $\mathrm{C}_{2} \mathrm{v}$.

${ }_{47} \mathrm{~W}$. Turner, A new dialogue..., k. $\mathrm{A}_{5} \mathrm{r} .-\mathrm{A}_{5} \mathrm{v} .:$ „, $[\ldots]$ and that $\mathrm{I}$ am the Popes doughter and haue driuen out of the churche the Supper of our Lord, and haue set up my selfe in the stead of it, and that I am the greatest blasphemy that euer was unto Christes death and passion [...] But ye good catholicke and Christen people knowe well enough, what I am and from whence I came. Ue wot that I cam from Christ and his Apostles”.

${ }^{4}$ Ibidem, k. A $\mathrm{A}_{8} \mathrm{r}-\mathrm{A}_{8} \mathrm{v}$.: „If the messe, after due examination, be founde to be good \& godlye she shall haue no harme, but if she be found to be of Antichrist \& but a fained thing, to win money w[ith] to the idle preistes that can not preache $[\ldots]$ ". 
Utwór Punta został za to konsekwentnie zaludniony wyłącznie personifikacjami. Verite i Knowledge zwracają się z inicjatywą wezwania Mszy do Mądrości (Wisdom), sprawującej administracyjne funkcje sądowe. Ten zarządza aresztowanie Mszy i ogłasza proces na kolejny dzień, mimo że Msza próbowała wykupić sobie wolność za pomocą łapówki. Sędzia w tym procesie określony jest po prostu jako The Iuge, ale spis interlokutorów poprzedzający dialog określa go tam także jako personifikację Słowa Bożego („Godes word the hei Iuge”49).

Jak widać, $w$ utworach angielskich bohaterowie są naocznymi świadkami wystąpienia Mszy albo źródło informacji jest czytelnikowi nieznane, u Ochina przeciwnie - rzecz jest sformułowana bardziej perswazyjnie: dobry chrześcijanin, jakim jest Miłośnik Chwały Bożej, zna Pismo i próbuje na jego podstawie dociec prawdy o losach Wieczerzy Pańskiej, a czytelnikowi jej losy znane są z poprzedniego aktu. Znacząca jest też różnica w skojarzeniach wywoływanych przez pozywających: podczas gdy Ochino akcentuje pobudki pobożnościowe, Turner i Punt kładą nacisk na to, że powód Knowledge wie o przestępstwach Mszy i jego celem jest wyjawienie ich innym chrześcijanom. Ranga sądu u Ochina jest wyższa, bo Mszę sądzi sam Duch Święty. Na marginesie warto zaznaczyć, że Ochino - choć był posądzany o antytrynitaryzm i inspirował na przykład doktryny braci polskich - oficjalnie odżegnywał się od takiego stanowiska, a jego poglądy na kwestię Trójcy najbliższe były trydeizmowi rozumianemu jako niechęć do opisywania tego dogmatu za pomocą scholastycznej terminologii ${ }^{50}$, czego pośrednim wyrazem może być (lecz o tym nie przesądza) potraktowanie w omawianym dialogu postaci Ducha Świętego odrębnie i niezależnie od pozostałych Osób Boskich.

Zwraca także uwagę, że spersonifikowana Wieczerza Pańska przeciwstawiona Mszy pojawia się tylko u Ochina, chociaż rola Mszy

49 W. Punt, Endighment..., k. A r.

50 Zob. L. Szczucki, Marcin Czechowic (1532-1613). Studium z dziejów antytrynitaryzmu polskiego XVI wieku, Warszawa 1964, s. 54-55 oraz s. 237-238, przyp. 131. O definicji i roli trydeizmu w ruchu antytrynitarskim zob. Z. Ogonowski, Socynianizm. Dzieje, pogladdy, oddziaływanie, Warszawa 2015, s. 59-61. 
w procesie jest zbliżona we wszystkich trzech tekstach. W utworze Turnera - trochę jak w polskim przekładzie Ochina - Msza z początku broni się sama, a następnie pałeczkę przejmują powołani dla niej obrońcy: Porfiriusz (Porphyrius) i Filargiusz (Philargyrie). Broni się samodzielnie w krótszym dialogu Punta i podobnie jak u Ochina próbuje najpierw przekonać, że przede wszystkim ze względu na jej pozycję w ogóle nie godzi się stawiać jej przed sądem ${ }^{51}$.

Nieco odmiennie układają się dominanty w sposobie konstruowania dyskusji w omawianych tekstach, chociaż zbliżony pozostaje repertuar zarzutów stawianych Mszy (co wynika raczej z czynników pozatekstowych i ogólnoeuropejskiego obiegu polemik z Rzymem). W dialogu Turnera nadrzędna jest kwestia genezy Mszy, a oskarżenie wychodzi od zarzutu braku biblijnych wzmianek o ceremonii w takim kształcie, jaki jest praktykowany przez Kościół rzymski; także wyrok sprowadza się do niemożności wykazania jakiejkolwiek zgodności mszy z Pismem. Zarówno u Punta, jak i u Ochina strategia jest odmienna: interpretacja Biblii nie jest punktem wyjścia do debaty, tylko wspiera osobne argumenty dotyczące między innymi nieuprawnionego ponawiania ofiary Chrystusa (którego śmierć na krzyżu miałaby być ofiarą wystarczającą), kształtu ceremonii, kwestii transsubstancjacji czy wreszcie nadużywania mszy jako swoistego magicznego remedium na niedole.

We wszystkich utworach wyroki są oczywiście dla Mszy niekorzystne. Angielscy pisarze ustami swoich literackich sędziów skazują ją na wygnanie z królestwa, Turner doprecyzowuje nawet, że Msza ma w ciągu ośmiu dni wrócić do swojego ojca papieża i zabrać

${ }^{51}$ Zob. W. Punt, Endighment..., k. B B $_{1}$.- $-\mathrm{B}_{1}$ v.: „I am she that hath ben of a long continuance, instituted \& made by christ and his apostles \& aprouid by diuers, holy doctors $\&$ for the space af this viC [=600?] yeares I haue ben taken $\&$ halowed among the the cheafest as a women mooste necessarie for the peoples saluatyon and seing that I am spirituall and Allowed by so many holy fathers ordeyned by the holy scryptures and aproued by diuers holy doctors, my think my lord you should not alow the accusations [...]". 
ze sobą wszystkie torby i pakunki ${ }^{52}$, czyli zapewne wystawne paramenty, sprzęty liturgiczne. W obu tekstach podkreśla się, że oskarżona została potępiona i zasługuje na śmierć, która grozi jej w razie próby powrotu z wygnania ${ }^{53}$. Utwór Turnera kończy się wygłoszoną w wyroku obietnicą prędkiego przegnania Mszy z kraju i tu lapidarność tego zapewnienia ma zapewne działać na czytelnika. Inaczej rozwiązał akcję Punt, który już po zakończeniu procesu każe wygłosić sędziemu ostateczną przemowę i zwrócić się po trosze do innych postaci w tekście, a po trosze do czytelników słowami „Now gentle audience..." ${ }^{\text {. }}$. Pozwala jeszcze raz wybrzmieć wszystkim argumentom, które padły w dialogu, a następnie wyraża nadzieję, że już wkrótce wszyscy będą „wieczerzać z Chrystusem”55, co stanowi odwołanie do sakramentu Wieczerzy Pańskiej, której miejsce zajęła Msza. U Ochina wyrok ma charakter ogólniejszy i zarazem donioślejszy, bo Duch Święty zobowiązuje każdego chrześcijanina (a nie tylko mieszkańców jednego królestwa), „aby [Msza - W.K.] już od wszystkich była wiecznie wzgardzona a odrzucona, a iżby ją wszyscy sobie mieli za podejrzaną i strzegli się jej jako Bożej nieprzyjaciółki i wszystkich dusz ludzkich"56. Jednak to nie wyrok zamyka utwór, a obszerna przemowa uwolnionej Wieczerzy Pańskiej, która zarazem rekapituluje najważniejsze punkty dyskusji sądowej i napomina

52 W. Turner, A new dialogue..., k. $\mathrm{G}_{8} \mathrm{r} .-\mathrm{G}_{8} \mathrm{v} .:$,I command the in payne of burying to parke out of this realme, w[ith]in al thi baggs \& baggage w[ith]in these VIII daies, \& to go to thy father the pope, [...] that here is in Englande no more place for him or any of his generation".

${ }^{53}$ Ibidem, k. G $\mathrm{v}$.: „I am contente, saie not woman, but thou arte warned, if that thou over come into this realme again after these viii daies, loke non other but to be serued euen as thi father hath serued oure brethern in time paste". W. Punt, Endighment..., k. $\mathrm{C}_{1} \mathrm{v}$.: „Wel woman by the worde of god thou art condemned unto death for treason theft and murder, and seyng thou arte so thou shalte dye the deathe".

54 Ibidem, k. $\mathrm{C}_{3} \mathrm{r}$.

${ }_{55}$ Ibidem, k. $\mathrm{C}_{5} \mathrm{r} .:$ „[...] to open the dore oure hartes I meane which is locked up in unbeleue that he may enter in and there is no dout then but that he wyll suppe wyth us and we with him unto the which supper I beseche the lord dringe us all unto".

56 B. Ochino, Trajedyja..., k. Ww ${ }_{1} \mathrm{r}$. 
wiernych: wzywa ich do praktykowania sakramentu Wieczerzy Pańskiej, podkreślając, jakie są różnice między tym „Chrystusowym” sakramentem a „bluźnierczą” Mszą.

Pomimo tkwiących w szczegółach różnic w sposobie odwoływania się do tego samego zamysłu przeprowadzenia krytyki Mszy powyższe zestawienie uzmysławia, jak bliskie są sobie trzy omawiane utwory. O ile więc drugi akt Trajedyi o Mszej, zawierający scenę sądu, stanowi analogiczną realizację tego samego schematu, który spotkamy u Turnera i Punta, o tyle akt pierwszy, ukazujący fabularyzowaną genezę Mszy i jej pochodzenie, jest pewną innowacją. Realizując te same założenia, utwory te mają swoje podłoże w szeroko rozumianej krytyce katolicyzmu ze strony reformatorów, przy czym w dialogach angielskich została ona wyłożona jako status quo w wypowiedziach postaci (Msza pochodzi od ludzi, jest córką papieża, zajęła miejsce należne Wieczerzy Pańskiej), a u Ochino - za pomocą podsumowania, w polskim tekście znajdującego się w pierwszym akcie, unaoczniającego czytelnikowi proces dochodzenia do tego stanu rzeczy, u którego źródła znajduje się zdaniem autora działalność diabelska.

Bevan Zlatar upatruje wzorców dla pamfletu Turnera w dziełach niemieckojęzycznych (zwłaszcza szwajcarskich), które znane mogły być podróżującemu po protestanckich krajach kontynentalnej Europy autorowi ${ }^{57}$. Wskazuje na utwory wykorzystujące konwencję procesu w polemicznych dialogach religijnych, takie jak Rychstag (1526) Utza Ecktseina czy rozmowy zawarte w niemieckich Dialogorum libri tres (1539) Georga Witzela. Z tego ostatniego dzieła zapożyczył zresztą Turner imię Palemona, występującego jako sędzia u Witzela i rozsądzającego spór teologiczny między zwolennikami różnych formujących się konfesji. Z kolei dla jednego z obrońców Mszy, Porfiriusza, Turner przejął imię z tragedii Pammachius (1538) Thomasa Kirchmeyera (Naogeorga), w której ten został wcześniej wprowadzony jako doradca Antychrysta. Badaczka zauważa także, że sam pomysł na kobiecą personifikację, która zostaje przez obywateli

57 Zob. A. Bevan Zlatar, Reformation..., s. 51. 
pochwycona i osądzona, może się wywodzić z karnawałowych, zazwyczaj anonimowych Fastnachtspielen, w których podobny los co Turnerowską Mszę spotyka uosobienie Karnawału ${ }^{58}$.

Należy przypomnieć, że Ochino jako uchodźca z Italii działał w wielu europejskich miastach: zarówno w Szwajcarii (na dłużej zatrzymał się w Genewie - w latach 1543-1545, a następnie w Bazylei i Zurychu w latach 1553-1563), jak i w Królestwie Anglii w latach 1547-1553, czyli właśnie wówczas, gdy toczyła się tam wymierzona w mszę kampania wydawnicza, której owocem były między innymi dialogi Turnera i Punta. Dlatego wydaje się prawdopodobne, że Ochino przynajmniej w zarysie znał fabuły angielskich utworów i stąd wziął pomysł na konstrukcję swojego tekstu. Choć możliwe, że zaznajomił się z konwencjami personifikowania mszy czy to w omawianych utworach szwajcarskich, czy to we włoskiej rozprawie Annotomia della messa (1552) Agostina Mainarda wykorzystującej sekcyjną metaforę do systematycznego wywodu teologicznego ${ }^{59}$, to koncepcja przeprowadzenia procesu uosobionej mszy każe zwrócić uwagę zwłaszcza na źródła angielskie.

Nie wiadomo nic o znajomości angielskiego przez Ochina: pisywał przede wszystkim po włosku, rzadziej po łacinie. Jego pozycja w Londynie była jednak wówczas dość wysoka, pracował jako główny kaznodzieja Kościoła Cudzoziemskiego i miał możnych angielskich przyjaciół, jak choćby arcybiskupa Canterbury Thomasa Cranmera czy biskupa Winchester Johna Poneta, który przetłumaczywszy na angielski dialog Ochina w Polsce znany jako $O$ zwierzchności

58 Ibidem.

59 A. Mainardo, Annotomia della messa, la qual scuopre gli enormi errori e gli infiniti abusi, dal volgo non conosciuti [...], [Zürich: Andreas Gesner, Rudolf Wyssenbach], 1552. Pierwsze wydanie zostało zredagowane przez Vergeria, zob. więcej: R.A. Pierce, Agostino Mainardo, Pier Paolo Vergerio and the "Anatomia Missae", "Bibliothèque d'Humanisme et Renaissance” 1 (1993); omówienie pierwodruku: ibidem: s. 37-38. 
papieskiej, wydał go dwukrotnie w 1549 roku $^{60}$. Jeszcze podczas pobytu reformatora w Londynie wydrukowano czterokrotnie zbiór jego kazań (po dwie edycje w 1547 i 1551, z czego późniejsze zostały poszerzone o dodatkowe teksty) ${ }^{61}$. O wysoko sięgających wpływach Ochina w protestanckiej Anglii świadczyć może także to, że uważnie studiował jego pisma nawet młodziutki król Edward VI, który jeden ze swoich traktatów-szkolnych wprawek poświęcił (najpewniej za radą nauczycieli) zagadnieniu supremacji papieskiej i dał wyraz dogłębnej znajomości dialogu Ochina. Ponieważ tekst ukazał się dopiero w 1549 roku, a monarcha spisywał rozprawkę pomiędzy grudniem 1548 a sierpniem 1549 roku, korzystał zapewne z łacińskiego rękopisu być może tego samego, z którego Ponet dokonał przekładu utworu do druku ${ }^{62}$. Ochino w Anglii był więc nie tylko gościem szukającym schronienia, ale też aktywnym działaczem i w pewnym sensie - jednym z wielu współtwórców nowego Kościoła. Jego zaangażowanie $\mathrm{w}$ angielską sferę publiczną nie jest dowodem znajomości omawianych tu utworów, ale na pewno pozwala domniemywać co najmniej o dobrej orientacji w ówczesnej produkcji wydawniczej, prowadzonych akcjach propagandowych i polityce religijnej Królestwa Anglii.

Osobną sprawą, nierozstrzygalną w tym miejscu, pozostaje recepcja Ochina w Polsce i drogi transferu jego dzieł do literatury polskiej, najprawdopodobniej podparte osobistymi relacjami z polskimi reformatorami. Jak zwracano uwagę na początku, nie orzekano zatem o stopniu modyfikacji pierwotnego tekstu Ochina przez polskiego tłumacza, przekład stanowi bowiem, wedle obecnej wiedzy, wybór z obszerniejszego utworu włoskiego, ale pozostaje wobec pierwowzoru wystarczająco wierny.

${ }^{60}$ B. Ochino, Tragoedie or dialoge of the unjuste usurped primacie of the Bishop of Rome, and of all the just abolishyng of the same, trans. J. Ponet, London: Nicholas Hill, 1549 (STC: 18771, 18771).

${ }^{61}$ Zob. STC: 18764, 18765, 18766, 18767.

${ }^{62}$ Zob. D. McCulloch, Tudor Church Militant. Edward VI and the Protestant Reformation, London 2017, s. 26-30. 
Nie analizowano tu szczegółowych różnic teologicznych, które wynikały czy to z różnej formacji i wykształcenia autorów (np. Turner był, jak sam deklarował w przedmowie, świeckim lekarzem, który chciał przekonywać swoich ziomków, Ochino - duchownym i wytrawnym teologiem), czy to innego tła konfesyjnego (głosów w dyskusji nad formowaniem Kościoła angielskiego za Edwarda VI i późniejszych poglądów Ochina, rezydującego od 1553 roku w Szwajcarii z jej silnie zróżnicowanymi wewnętrznie stanowiskami teologicznymi spiętymi w ugodowej formule Consensus Tigurinus). Jednak zbieżności o charakterze literackim (konstrukcja dialogowa, sceny sądu, personifikowanie mszy) pozwalają mówić o pośrednim przeniesieniu wzorców angielskich do literatury polskiej poprzez tłumaczenie utworu włoskiego autora, co z pewnością pomoże wzbogacić wiedzę o wciąż słabo zbadanych i częstokroć okrężnych polsko-angielskich kontaktach kulturowych ${ }^{63}$. W konsekwencji można obserwować, jak zastosowano podobne rozwiązania kompozycyjne oraz topikę służące w pierwszym rzędzie perswazji religijnej - w protestanckich wypowiedziach o charakterze polemicznym przeciwko mszy, lecz w różnych realiach.

\section{Bibliografia}

\section{Źródła}

Atrocianus I., Querela Missae [...] opusculum elegans ac recens natum atque excusum, Basel: Johannes Faber aus Emmich, 1529.

[Barlowe J., Roy W.], The boke reade me frynde and be not wrothe, for I saye nothynge but the trothe. The byshoppes speake in the Cardynall. I wyll ascende makynge my state so hye, that my pompouse honoure shall neuer dye, [Antwerpen?] 1546.

${ }^{63}$ Ostatnio o literackich polsko-angielskich kontaktach, między innymi reformacyjnych, pisała Mirosława Hanusiewicz-Lavallee, W stronę Albionu. Studia $z$ dziejów polsko-brytyjskich związków literackich $w$ dobie wczesnonowożytnej, Lublin 2017. 
Barlowe J., Roy W., Rede me and be nott wrothe, ed. by D.H. Parker, Toronto 1992. [Barlowe J., Roy W.], Rede me and be nott wrothe for I saye no thynge but trothe. I will ascende makynge my state so hye, that my pompous honoure shall never dye, [Strasbourg: Johannes Schott, 1528].

Mainardo A., Annotomia della messa, la qual scuopre gli enormi errori e gli infiniti abusi, dal volgo non conosciuti [...], [Zürich: Andreas Gesner, Rudolf Wyssenbach], 1552.

Manuel N., Krankheit und Testament der Messe, w: idem, Werke und Briefe. Vollständige Neuedition, hrsg. von T. Hengartner, P. Zinsli, Bern 1999.

Ochino B., Disputa intorno alla presenza del corpo di Giesu Christo nel sacramento della cena, Basel: [Peter Perna?], 1561.

Ochino B., Liber de corporis Christi praesentia in coenae sacramento, Basel: Peter Perna, 1561.

Ochino B., O zwierzchności papieskiej nad wszystkim światem krześcijańskim tragedyja krotochwilna, nauki krześcijańskiej barzo potrzebnej, papieskie fałsze okazującej i burzacej pełna, przeł. E. Trepka, Szamotuły: Aleksander Augezdecki, 1558.

Ochino B., Tragoedie or dialoge of the unjuste usurped primacie of the Bishop of Rome, and of all the just abolishyng of the same, trans. J. Ponet, London: Nicholas Hill, 1549.

Ochino B., Trajedyja o Mszej, z której każdy snadnie wyrozumieć może początek $i$ wszelaka jej sprawe, i do prawdziwej Wieczerzej Pańskiej właśnie każdy wiedzieć ma, Pińczów: Daniel z Łęczycy, 1560.

Postępek prawa czartowskiego przeciw narodowi ludzkiemu, [Brześć Litewski: Cyprian Bazylik, 1570].

Postępek prawa czartowskiego przeciw narodowi ludzkiemu, oprac. A. Kochan, Wrocław 2015.

Punt W., Endighment agaynste the Mother Messe, [London: William Hill, William Seres, 1548].

Rej M., Apocalypsis, red. W. Kriegseisen, oprac. M.M. Kacprzak, S. Kawczyński, J.T. Maciuszko, I. Winiarska, Warszawa 2005.

[Shepherd L.], Pathose or An inward passion of the pope for the losse of hys daughter the masse, [London: John Day, William Seres, 1548].

Shepherd L., Pathose or An inward passion of the pope for the losse of hys daughter the masse, w: An Edition of Luke Shepherd's Satires, ed. by J. Devereux, Tempe (Ariz.) 2001.

Shepherd L., Upcheringe of the messe, London: John Day, William Seres, [1548].

Shepherd L., Upcheringe of the messe, w: An Edition of Luke Shepherd's Satires, ed. by J. Devereux, Tempe (Arizona) 2001.

Tengler U., Layenspiegel von rechtmässigen Ordnungen in burgerlichen und peinlichen Regimenten, Augsburg: Johann Otmar, 1509.

[Trepka E.?], Książki o tym, skąd wzięło początek słowo Boże, Królewiec: Hans Daubmann, 1557. 
Turner W., A new dialogue wherin is conteyned the examinatio $[n]$ of the Messe, and of that kynde of priesthode, whych is ordeined to saye Messe, [London: William Hill, 1548].

Wanner V., Praktyka o mszy, co o niej a jako rozumieć mamy, [przeł. W. Nowomiejski], Królewiec: Hans Daubmann, 1559.

\section{Opracowania}

Allen M., Sacraments in the Reformed and Anglican Reformation, w: The Oxford Handbook of Sacramental Theology, ed. by H. Boersma, M. Levering, Oxford 2018. Barnes R.B., Astrology and Reformation, Oxford 2016.

Barycz H., Lismanin Franciszek, w: Polski słownik biograficzny, t. 17, Kraków 1972. Bevan Zlatar A., Reformation Fictions. Polemical Protestant Dialogues in Elizabethan England, Oxford 2011.

Brückner A., O różnowierstwie polskiem słów kilka, „Reformacja w Polsce” 1 (1921).

Burnett A.N., Karlstadt and the Origins of the Eucharistic Controversy. A Study in the Circulation of Ideas, Oxford 2011.

Cardelle de Hartmann C., Lateinische Dialoge 1200-1400. Literaturhistorische Studie und Repertorium, Leiden 2007.

Greisenegger W., Ecclesia, w: Lexikon der christliche Ikonographie, hrsg. von E. Kirschbaum, Bd. 1, Rom 1968.

Guerra C., Die Werke im Überblick, w: Johannes Atrocianus. Text, Übersetzung, Kommentar, hrsg. von C. Guerra, H. Harich-Schwarzbauer, J. Hindermann, Hildesheim 2018.

Hanusiewicz-Lavallee M., W stronę Albionu. Studia $z$ dziejów polsko-brytyjskich zwiazków literackich $w$ dobie wczesnonowożytnej, Lublin 2017.

Johannes Atrocianus. Text, Übersetzung, Kommentar, hrsg. von C. Guerra, H. Harich-Schwarzbauer, J. Hindermann, Hildesheim 2018.

Kampe J., Problem „Reformationsdialog“. Untersuchungen zur einer Gattung im reformatorischen Medienwettstreit, Tübingen 1997.

Kleiner J., „Tragedye” Ochina, „Pamiętnik Literacki” 9 (1910), z. 4.

Kochan A., Kupiec przed polskim sądem. Uwagi i komentarze do „Kupca” Mikołaja Reja, „Pamiętnik Literacki” 94 (2003), z. 4.

Maciuszko J.T., Mikołaj Rej. Zapomniany teolog ewangelicki zXVI w., Warszawa 2002. Mattox M.L., Sacraments in the Lutheran Reformation, w: The Oxford Handbook of Sacramental Theology, ed. by H. Boersma, M. Levering, Oxford 2018.

McCulloch D., Tudor Church Militant. Edward VI and the Protestant Reformation, London 2017.

Ogonowski Z., Socynianizm. Dzieje, poglady, oddziaływanie, Warszawa 2015.

Parker D.H., Prologue, w: J. Barlowe, W. Roy, Rede me and be nott wrothe, ed. by D.H. Parker, Toronto 1992. 
Pierce R.A., Agostino Mainardo, Pier Paolo Vergerio and the "Anatomia Missae", „Bibliothèque d'Humanisme et Renaissance” 1 (1993).

Płaza S., Historia prawa w Polsce na tle porównawczym, cz. 1, Kraków 2003.

Pollard A.W., Redgrave G.R., Short Title Catalogue, $2^{\text {nd }}$ ed., London 1976-1991, www.estc.bl.uk (dostęp: 20.12.2018).

Russell P.A., Lay Theology in the Reformation. Popular Pamphleteers in Southwest Germany 1521-1525, Cambridge 2002.

Ryszka-Kurczab M., Mimetyczny charakter szesnastowiecznych dialogów. Preliminaria, w: „Wszystko tu najdzie, co wy macie w głowie”. Świat prozy staropolskiej, red. E. Lasocińska, A. Czechowicz, Warszawa 2008.

Schairer I.B., Das religiöse Volksleben am Ausgang des Mittelalters nach Augsburger Quellen, Leipzig 1914.

Spurgeon D., Introduction, w: Three Tudor Dialogues, ed. by D. Spurgeon, New York 1978.

Szczucki L., Marcin Czechowic (1532-1613). Studium z dziejów antytrynitaryzmu polskiego XVI wieku, Warszawa 1964.

Ślaski J., Le "Tragedie" di Bernardino Ochino in polacco, w: Movimenti ereticali in Italia e in Polonia nei secoli XVI-XVII. Atti del convegno italo-polacco, Firenza, 22-24 settembre 1971, Firenze 1974.

Thompson N., Eucharistic Sacrifice and Patristic Tradition in the Theology of Martin Bucer, 1534-1546, Leiden 2005.

Three Tudor Dialogues, ed. by D. Spurgeon, New York 1978.

Wojtkowski J., Kanoniczne podstawy dialogu Maryi z szatanem w procesie szatana przeciwko rodzajowi ludzkiemu Bartola z Sassoferrato, „Studia Warmińskie” 41/42 (2004/2005).

Ziomek J., Mikołaja Reja „Krótka rozprawa” i „Kupiec”. Problemy dialogu i dramatu, w: Mikołaj Rej w czterechsetlecie śmierci, red. T. Bieńkowski, J. Pelc, K. Pisarkowa, Wrocław 1971. 